\title{
Analysis of Influencing Factors of City Center Migrant Population Social Integration Social Survey Based on Nanjing Xiangpuying Community
}

\author{
Jie Yin, Daxi Kang \\ Nanjing Forestry University, College of Landscape Architecture, Nanjing 210037, China.
}

Keywords: city center; migrant population; social integration; influence factor; Nanjing, China.

\begin{abstract}
A lot of migrant population engaged in tertiary industry has entered city center area with expansion and upgrading of city center industrial structure, it is regarded as the starting point in the study. Binary Logistic regression analysis method is adopted based on survey data of Nanjing Central Urban Area Xiangpuying Community, influence factors of city center migrant population social integration are surveyed from two aspects of individual elements and social space element. Results show that the influence of social space factors related to immigration destination institutional environment and social development status on social integration is larger than that of individual factors on social integration generally. The social integration status of migrant population is related to migrant population habitable space in many aspects.
\end{abstract}

\section{Introduction}

Migration population among different regions in China is increasing continuously after the reform and opening up, with the continuous acceleration of China urbanization process. However, China industrialization, urbanization and citizenization are not consistent in the aspect development process, which is different from urbanization and migration process in foreign countries [1]. China unique 'household registration system'is regarded as a structural obstacle. China domestic migration population mostly realizes spatial flowing only, and they fail in citizenization and integration with city society at the social level of destination, thereby forming Chinese unique population migration group with separated household registration and residence--- 'migrant population' Currently, migrant population still has disadvantages in the aspects of individual development potential, social equity allocation, system support and social interaction compared with indigenous inhabitant. The vast majority of migrant population still has 'marginalization' role in China urban development and construction. Related issues of social integration in China migrant population have always been the focus of government and academia.

Social integration, as a classical research topic of sociology, belongs to a multi-dimensional concept. Chinese scholars referred to the study of foreign scholars on social integration of multinational immigrants and ethnic minorities [2-3], and conducted a lot of research on the influence factor of China migrant population social integration [4]. Domestic scholars also believe that the factors such as human capital, social capital, cultural psychology and destination institutional arrangement of migrant population have a strong correlation with social integration degree [5]. In addition, China migrant population is no longer a highly homogeneous group in the new period, and its social integration process also showed the new features of differentiation, which is mainly manifested through social characteristic difference and spatial characteristic differences [6]. Wherein, foreign scholar Massey proposed 'Spatial Assimilation' as early as last century at the spatial level [7], he proposed that different residential locations of foreign multinational immigrants in the city is strongly related to the social integration degree. The viewpoint also has been proved by some domestic studies in recent years. It is discovered that there are many differences of migrant population social integration in different spaces, regions and even communities [8]. In fact, the habitable space of migrant population entering into cities can be roughly divided into three categories in China [9]: residence in 'village' urban edge habitable space; centralized residence in unit dormitory and work shed in the industrial space on the edge of the city and residence in city center apartments. However, related studies mostly focus on social integration status and influence factors of migrant 
population in two former city material space edge sections. Targeted and concrete discussion is insufficient for social integration influence factor of migrant population living in the city, who realizes superposition with destination citizen habitable space.

On the basis, migrant population habitable space of existing community in Nanjing city center, China under the new era is selected in the study. Based on the data of the field survey. Binary Logistic regression model is applied for studying social integration influence factors from two aspects of social space factors related to migrant population habitable space region and its migrant population as well as individual factors related to socioeconomic features, thereby further comprehending the difference of migrant population social integration in different orders, groups and spaces, and comprehensively mastering the features of migrant population social space in China urbanization process comprehensively.

\section{Selection and Analysis Methods of Survey Region}

\subsection{Selection of Survey Region and Its Basic Situation}

Xiangpuying Community, one of the clusters of migrant population in the central urban area of Nanjing, Jiangsu Province, China, is regarded as survey region in the study. Xiangpuying Community is a typical city center community. It is adjacent to Nanjing largest business circle 'Xinjiekou', which is administered by Xinjiekou Subdistrict Office of Nanjing Xuanwu District. The community is close to Zhujiang Road, Zhongshan Road, Taiping Road and other main roads in Nanjing. It is worthy of the name 'city center'. The service facilities are complete and the location conditions are excellent around the survey region. The industry is dominated by ternary industry. The specific business types are rich. However, the development scale of related industries is uneven. The community covers an area of about 0.44 square kilometers according to the survey data. Permanent population is about 18,500 . The migrant population is about 6,500 , and most population are engaged in the industry. Therefore, Xiangpuying Community is regarded as a typical example of city center migrant population habitable space in the new era, and its migrant population inside the city engaged in tertiary industry is the representative of migrant population entering into the city center. It is regarded as the survey region in the study, thereby trying to discover social integration process of city center migrant population from the micro perspective in the study.

\subsection{Research Method and Data Source}

\subsubsection{Binary Logistic Regression Analysis}

Related studies of domestic scholars are combined in the study, binary Logistic model is applied to explore social integration influence factor of city center migrant population from two aspects of individual factors and social space factors in order to study influence factor of city center migrant population social integration. In the aspect of dependent variable, the following question in the questionnaire is selected in the study express the social integration degree of migrant population 'are you willing to move your registered permanent residence to Nanjing if there is no condition restrictions?', it is regarded as explained variables, the value is 0 or 1 (people willing to move the registered permanent residence, $y=1$; people unwilling to move the registered permanent residence, $\mathrm{y}=0$ ). In the aspect of independent variable, related studies are referred, a total of 14 indicators are regarded as social integration concrete influence factors of city center migrant population in the study, namely individual factors (gender, marital status, Level of education, training participation, inbound time and migration mode) and social space factors (residence status, occupation category, personal income, residence permit transaction or not, quantity of urban social insurances, satisfaction degree for using habitable space surrounding public service facility, community involvement condition and social interaction objects), they are regarded as independent variables for definition and assignment, which are brought into binary Logistic regression model for analysis. The social integration influence factor of city center migrant population are tested in the aspect of statistical significance, concrete assignment method is shown in table 1. 


\section{Data Source}

Field survey, questionnaire and semi-structured interview methods are adopted in the study in 2017 for investigating migrant population in Xiangpuying Community. The research objects include migration population living in the community for more than six months without local permanent registered residence from 18 to 59 years old. The research content involves residents' economic capacity, routine life style, social interaction, social service enjoyment and identity between migrants and local population, etc. The questionnaire survey was conducted by random sampling in the study, and a total of 250 questionnaires were distributed, including 240 valid questionnaires, and the recovery rate was $96 \%$.

\section{Results and Analysis}

SPSS software is applied for binary Logistic analysis on above selected independent variable and dependent variable in the study. Results show that model-2 Loglikehood (log likelihood) is 339.112, the test value of Hosmer and Lemeshow is 17.291 (sig=0.047), NagelkerkeR2 is 0.3742, and the model has excellent fitting degree as a whole. In general, social space factors have the largest influence on social integration of city center migrant population, the regression coefficients and significance level of all concrete factors are higher except occupation category factors (B absolute values are higher than 0.95 , and all values are significant at the level of $0.1 \%$ and $1 \%$ ), regression coefficient values of individual factors are different, and the influence on its social integration is relatively low. Eight factors playing significant role to city center migrant population social integration are respectively shown as follows in descending order (B value is higher than 1 ): quantity of urban social insurances, level of education, personal income, training experience, social network composition, residence permit transaction or not, surrounding public service facility satisfaction degree and gender. (Table 2 and Table 3).

\subsection{Individual Factors}

Individual factors include individual basic feature, human capital level, migration feature, etc. of migrant population, wherein migrant population education level and training experience have extremely significant and positive influence on migrant population social integration, higher education level and training experience ( regression coefficients are respectively 2.561 and 2.032, and they are significant at $0.1 \%$ confidence level) have significant promotion role to social integration of city center migrant population. Longer education period and work training experience are beneficial for city center migrant population to obtain better occupation development potential. They can achieve higher economic income on the basis.

Fender variable has certain positive role to social integration of city center migrant population in other individual factors, but the influence is insignificant, namely male social integration degree is relatively high (regression coefficient is 1.087), which may be related to higher social expectation undertaken by males in society and family. Inbound time and migration mode have certain positive influence on social integration of city center migrant population (regression coefficients are respectively 0.701 and 0.937 ), they are both qualified in significance test. It is obvious that migrant population and urban-urban migration population with longer inbound time have higher social integration level. Marital status variable is not qualified in significance test. However, it can be roughly concluded that social integration intention and degree of unmarried group may be higher. 
Table 1. assignment and definition of migrant population social integration influence factor variable statistics

\begin{tabular}{|c|c|c|}
\hline Variable type & Variable name & Variable definition \\
\hline $\begin{array}{l}\text { Independent } \\
\text { variable }\end{array}$ & City settlement intention & Yes $=1$, no $=0$ \\
\hline \multirow{6}{*}{$\begin{array}{l}\text { Individual } \\
\text { factors }\end{array}$} & Gender (female) & Female $=0$, male $=1$ \\
\hline & Marital status (unmarried ) & Unmarried $=0$, married $=1$ \\
\hline & $\begin{array}{l}\text { Level of education (primary } \\
\text { school or below) }\end{array}$ & $\begin{array}{c}\text { Primary school or below=0, senior middle school =1, junior middle } \\
\text { school/technical secondary school=2, junior college=3, bachelor degree=4, } \\
\text { graduate student }=5\end{array}$ \\
\hline & $\begin{array}{l}\text { Training experience (no } \\
\text { training experience ) }\end{array}$ & No training experience $=0$, participation of occupational training $=1$ \\
\hline & $\begin{array}{l}\text { Inbound time (less than } 1 \\
\text { year ) }\end{array}$ & Less than 1 year $=0,1-2$ years $=1,2-3$ years $=2,3$ years and below $=3$ \\
\hline & $\begin{array}{l}\text { Migration mode (rural-urban } \\
\text { migration) }\end{array}$ & Rural-urban migration $=0$, urban-urban migration $=1$ \\
\hline \multirow{8}{*}{$\begin{array}{l}\text { Social space } \\
\text { element }\end{array}$} & $\begin{array}{l}\text { Occupation category (people } \\
\text { without regular work) }\end{array}$ & $\begin{array}{c}\text { People without regular work=0, business service employee =1, privately or } \\
\text { individually-owned business=2, private enterprise employee }=3 \text {, ordinary } \\
\text { employees of state-owned enterprises=4, enterprise (business) management } \\
\text { and management personnel=5, administrative and public institution } \\
\text { personnel=6 }\end{array}$ \\
\hline & $\begin{array}{l}\text { Personal income (income of } \\
\text { less than } 2000 \text { yuan ) }\end{array}$ & $\begin{aligned} \text { Less than } 2000=0,2001-4000 & =1,4001-6000=2,6001-8000=3,8001 \text { and } \\
& \text { more }=4\end{aligned}$ \\
\hline & $\begin{array}{l}\text { Residence status (renting of } \\
\text { private house ) }\end{array}$ & $\begin{array}{l}\text { Joint rent with other people }=0 \text {, family integral rental=1, dormitory } \\
\text { provided by the unit }=2 \text {, temporary residence in house of relative or friend }=3 \text {, } \\
\text { own house }=4\end{array}$ \\
\hline & $\begin{array}{l}\text { Residence permit transaction } \\
\text { or not (no residence permit } \\
\text { transaction ) }\end{array}$ & No residence permit transaction $=0$, residence permit transaction $=1$ \\
\hline & $\begin{array}{l}\text { Quantity of urban social } \\
\text { insurances (no urban social } \\
\text { insurance) }\end{array}$ & $\begin{array}{c}\text { No urban social insurance }=0,1 \text { insurance }=1,2 \text { insurances }=2,3 \text { insurances } \\
\qquad=3,4 \text { insurances }=4,5 \text { or more insurances }=5\end{array}$ \\
\hline & $\begin{array}{l}\text { Public service facility } \\
\text { satisfaction degree (unsatisfied ) }\end{array}$ & Unsatisfied $=0$, general $=1$, more satisfactory $=2$ \\
\hline & $\begin{array}{l}\text { Community involvement } \\
\text { condition (no participation) }\end{array}$ & $\begin{array}{c}\text { No participation }=0 \text {, annual participation }=1 \text {, monthly participation }=2 \text {, } \\
\text { weekly participation }=3\end{array}$ \\
\hline & $\begin{array}{c}\text { Social network composition } \\
\text { condition (countrymen/relative ) }\end{array}$ & Countrymen $/$ relative $=0$, migrant population $=1$, indigenous inhabitant $=2$ \\
\hline
\end{tabular}

Note: the secondary indicators in the brackets are reference groups. 
Table 2. Results of logistic regression analysis on individual factors

\begin{tabular}{|c|c|c|c|c|}
\hline & & $\mathrm{B}$ & Wals & Sig \\
\hline \multirow{6}{*}{ Individual factors } & Gender & $1.087^{*}$ & 5.532 & 0.019 \\
\hline & Marital status & -0.861 & 2.087 & 0.092 \\
\hline & Level of education & $2.561^{* * *}$ & 14.769 & 0.000 \\
\hline & Training experience & $1.932^{* * *}$ & 8.922 & 0.000 \\
\hline & Inbound time & $0.701^{*}$ & 4.015 & 0.037 \\
\hline & Migration mode & $0.937^{* *}$ & 4.941 & 0.007 \\
\hline
\end{tabular}

Note: ${ }^{* * *},{ }^{* *}$ and $*$ respectively represent significance at the level of $0.1 \%, 1 \%$ and $5 \%$.

Table 3. Results of logistic regression analysis on social space factors

\begin{tabular}{ccccc}
\hline & Variable & B & Wals & Sig \\
\hline & Occupation category & 0.651 & 2.893 & 0.059 \\
& Personal income & $2.287^{* * *}$ & 8.519 & 0.000 \\
Residence status & $-0.939^{*}$ & 3.269 & 0.039 \\
Social space factors & $1.401^{* * *}$ & 7.129 & 0.000 \\
& Residence permit transaction or not & $2.841^{* * *}$ & 17.587 & 0.000 \\
& Quantity of urban social insurances & $1.213^{* *}$ & 8.141 & 0.002 \\
& Surrounding public service facility satisfaction degree & $0.981^{* *}$ & 7.371 & 0.008 \\
& Community involvement condition & $1.843^{* *}$ & 7.434 & 0.007 \\
\hline
\end{tabular}

Note: ${ }^{* * *},{ }^{* *}$ and $*$ respectively represent significance at the level of $0.1 \%, 1 \%$ and $5 \%$.

\subsection{Social Space Element}

Social space elements mainly include destination institutional environment, community support, social network and economic support in the region. Wherein, income level and their social insurance quantity of the city center migrant population (regression coefficient B is 2.287 and 2.841, and it is significant at $0.1 \%$ confidence level) have extremely significant and positive influence on social integration thereof. High correlation of income level and social integration may be related to relatively high income and consumption level of the city center area. High income migrant population has wider choices, rights and ability of adapting to and integrating into city life. Migrant population with relatively low income can further compress daily consumption expenditure according to own development expectation and social positioning. More social insurances always mean more stable working income and daily life state in the aspect of social insurance quantity, migrant population can obtain more social development resources from the institutional aspect, which is beneficial for realizing its identity change.

The migrant population occupation type variable is related to its social integration degree to certain degree apart from the above two factors, it is unqualified in significance test, which may be related to lower industry level of migrant population in the sample. The residence status is negatively correlated with the social integration of city center migrant population, but it is not significant. Namely, the migrant population renting houses in the city have higher degree of social integration. Residence permit transaction or not has relatively significant positive influence on the satisfaction degree of public service facility near the destination, and social network composition condition has relatively significant positive influence on the social integration of city center migrant population (regression coefficients are 1.401, 1.213 and 1.843), namely city center migrant population with residence permit transaction, higher satisfaction degree to surrounding public service facility, positive and localized social network have relatively high social integration. In addition, community involvement also has certain positive influence on social integration, but it is not significant. Namely, higher community involvement can assist migrant population to accumulate local social capital to certain degree. 


\section{Conclusion and Discussion}

Binary Logistic model is used to analyze the influence factor of social integration in the paper based on field survey data of city center migrant population in Nanjing. The study finds that the social integration of city center migrant population is a complex process determined by individual factors and social space factors, both factors affect social integration. However, they show certain tendency. The social space factors related to migrant population destination social, institutional and community support, migrant population social interaction space and the economic support obtained by migrant population in the area have the largest influence on the social integration, wherein quantity of urban social insurances, personal income, social network composition, residence permit transaction or not and surrounding public service facility satisfaction degree have significant influence on social integration of city center migrant population. Other factors have lower influence on the social integration except education background and education level at the level of individual factors. The migrant population social integration is closely related to the residence survival space after migrant population enters into the city.

Therefore, 'National implementation of new urbanization (2014-2020)'plan promulgated in China is regarded as the core. Overall level of education and vocational skill level of migrant population are further improved as a whole, more outgoing and inclusive destination institutional environment should be constructed in a targeted mode, the correlation between household registration system and various city life rights and interests should be reduced, the city social security coverage group should be further expanded, and the equalization of basic public services should be promoted, and they are important means to accelerate the process of migrant population social integration. Meanwhile, habitable space also should be regarded as the basic carrier for promoting migrant population social integration. Basic service supply mechanism of the community should be further perfected, thereby creating sound residence and life working environment for migrant population, and further improving the social integration level.

\section{Acknowledgments}

This work was financially supported by The National Natural Science Foundation of China, (No. 41571157).

\section{References}

[1]. Li Zhuhai, Huang Ying. Research on 'peri-urbanisation' and 'citizenization'- city formal migration issue under the background of new urbanization. Planner, 2013, 29(4):32-36.

[2]. Penning R. Integration of migrants. Economic, social, cultural and political dimensions [J]. New Demographic Regime Population Challenges \& Policy Responses, 2005:137-152.

[3]. Alba R, Nee V. Rethinking Assimilation Theory for a New Era of Immigration [J]. Int Mir Rev, 1997, 31(4):826-874.

[4]. Yang Jurua. Research on social integration of Chinese migrant population. Social Sciences in China, 2015(2):61-79.

[5]. Zhang Winching, Lei Taichung. Analysis on structure of city new migrant social integration, status and influence factor. Study of Sociology, 2008(5):117-141.

[6]. Wang Ming Feng, Cheng Hong, Ming Yemen. Social integration of migrants of Shanghai urban village and influence factor thereof. Journal of Geographical Sciences, 2015, 70(8):1243-1255.

[7]. Massey D S. Ethnic residential segregation: a theoretical synthesis and empirical review [J]. Sociology \& Social Research, 1985, 69(3):315-350.

[8]. Tong Xin. Sociology of Population. The 4th Version. Peking University Press, 2010. 
[9]. Yu Yunjiang, Sun Binding, Sun Xu. Research on social integration level spatial difference of city migrants based on ESDA - with Shanghai as an example. Human Geography, 2014(2):123-128.

[10]. Zhang Zheng Research on residence of China migrant population. Population Journal, 2005(2):16-20. 